Brazilian Journal

of Chemical

Engineering

\title{
LIPIDS AS COMPETITIVE INHIBITORS OF SUBTILISIN CARLSBERG IN THE ENZYMATIC HYDROLYSIS OF PROTEINS IN RED TILAPIA (Oreochromis sp.) VISCERA: INSIGHTS FROM KINETIC MODELS AND A MOLECULAR DOCKING STUDY
}

\author{
Leidy J. G. Sampedro ${ }^{1}$, Nathalia A. G. Grimaldos ${ }^{1}$, \\ Jaime A. Pereañez ${ }^{2}$ and José E. Z. Montoya ${ }^{1 *}$

\begin{abstract}
${ }^{1}$ University of Antioquia, Faculty of Pharmaceutical and Food Sciences, Department of Food, Medellin, Colombia. ORCID: 0000-0001-9078-7051; ORCID: 0000-0003-0232-4271; E-mail: edgar.zapata@udea.edu.co - ORCID: 0000-0003-2733-1515

${ }^{2}$ University of Antioquia, Faculty of Pharmaceutical and Food Sciences, Department of Pharmacy, Medellin, Colombia. ORCID: 0000-0001-9612-2827
\end{abstract}

(Submitted: July 23, 2018 ; Revised: November 17, 2018 ; Accepted: December 14, 2018)

\begin{abstract}
Protein hydrolysis can improve food's nutritional, techno-functional and biological properties, which can increase the possibilities of application in industry. The objective of this research article was to study the effect of lipids on the enzymatic kinetics of red tilapia viscera (RTV) hydrolysis with subtilisin Carlsberg. The RTV were hydrolyzed in an enzyme/substrate ratio of $0.153(\mathrm{U} / \mathrm{g})$, at $53^{\circ} \mathrm{C}$, at a pH of 9.5 , initial concentrations of lipids of 1,19 and $50 \mathrm{~g} / \mathrm{L}$, and different initial substrate concentrations for each initial lipid concentration. To explain the lipid action mechanism, we evaluated a Michaelis-Menten model and another semi-physical model based on kinetic expressions and mass balances. Additionally, a molecular docking analysis was performed between subtilisin Carlsberg and the main fatty acid in RTV (palmitic acid). For both models, the results suggest a strong competitive inhibition by lipids, with an inhibition constant of 2.36 and $3.01 \mathrm{~g} / \mathrm{L}$ for the first and second models, respectively. On the other hand, docking suggested that palmitic acid could form van der Waals interactions and hydrogen bonds with the residues of the active site of subtilisin Carlsberg and occupy part of the substrate binding site, thus acting as an effective competitive inhibitor.

Keywords: Enzymatic hydrolysis; Competitive inhibition; Subtilisin Carlsberg; Modelling; Molecular docking.
\end{abstract}

\section{INTRODUCTION}

Red tilapia (Oreochromis sp.) viscera (RTV) are one of the major byproducts of the processing industry of the species ( $18 \%$ of the fish's weight) and have an elevated content of high-quality proteins (Martínez et al., 2015). This makes them an interesting substrate for enzymatic hydrolysis processes, which are especially attractive at present due to the possibility of generating bioactive peptides from them (Batista et al., 2010; Bhaskar and
Mahendrakar, 2008; Hathwar et al., 2011; He et al., 2013). This process entails a certain level of complexity due to the indefinite nature of the substrate, the presence of multiple substrates and reactions, the heterogeneity of the sample, and the inactivation of the enzyme due to various factors (Valencia et al., 2015). Despite the complexity of the reaction, several equations have been developed to model the enzymatic hydrolysis of proteins with different substrates and enzymes. Said models range from the classic Michaelis-Menten

\footnotetext{
* Corresponding author: José E. Zapata - E-mail: edgar.zapata@udea.edu.co
} 
approach (Demirhan et al., 2011; Trusek-Holownia, 2008; Valencia et al., 2014), to more complex models that incorporate enzyme inhibition and inactivation (Demirhan et al., 2011; Figueroa et al., 2012; Valencia et al., 2014); Empirical models using polynomial expressions and artificial neural networks are also used to model this process (Morales et al., 2016; Ojha et al., 2016; Pérez et al., 2011).

One of the most common mathematical models used to define the kinetic parameters of the enzymatic hydrolysis of proteins was developed by Marquez and Fernandez in 1993, who were able to reach a simple logarithmic equation by basing themselves on kinetic mechanisms and mathematical deductions (Marquez and Fernandez, 1993). This equation models the degree of hydrolysis (DH) as a function of the reaction time, considering two kinetic constants: $a$ and b. From this mathematical model, Qi and He (2006) deduced a series of expressions for the $\mathrm{a}$ and $\mathrm{b}$ parameters: when there is inhibition by a substrate or by a product, when these two are combined, or when there is no inhibition at all.

However, none of these models involve inhibition of proteolytic enzymes by components that are foreign to the hydrolysis process, which can be very important when dealing with substrates as complex as fish viscera. Besides containing different types of proteins, fish viscera also contain other components that could affect the interaction of the protein with the enzyme (Fischer et al., 2001; Rawel et al., 2002). The main components of the viscera besides water are lipids (Villamil et al., 2017), which can form protein-lipid complexes that prevent the catalytic action of enzymes on proteins (Šližyte et al., 2005), or interact directly with the enzyme, thus affecting the development of the hydrolysis reaction and the possibility of obtaining peptides. Previous studies have shown a negative effect of fat concentration on $\mathrm{DH}$ in the hydrolysis of RTV (Gómez and Zapata, 2017). However, this phenomenon has not been researched sufficiently. The objective of this research article was to study the inhibition activity by lipids present in the RTV on subtilisin Carlsberg during the process of enzymatic hydrolysis of RTV proteins.

\section{MATERIALS AND METHODS}

\section{Materials}

The RTV were obtained from Piscícola El Gaitero's cold chain (in Antioquia, Colombia), by taking samples from different production batches. Said viscera were homogenized and heated to $90^{\circ} \mathrm{C}$ for 20 minutes to inactivate the endogenous enzymes and remove most of the lipids. Subsequently, the aqueous and lipid fractions were stored separately at $-20^{\circ}$ C. Hydrolysis was carried out with Alcalase $2.4 \mathrm{~L}$, a serine endopeptidase that consists primarily of subtilisin Carlsberg (EC 3.4.21.62), which was produced via fermentation of Bacillus licheniformis (Novo Nordisk Co., Denmark).

\section{Proximal Analysis}

Humidity, ash, crude protein, and total lipid determinations were carried out according to the AOAC official methods for stove drying (AOAC 950.46), calcination (AOAC 942.05), Kjeldahl (AOAC 992.15) and dry extraction (AOAC 960.39), respectively (AOAC, 2006).

\section{Determination of total peptide bonds}

The total $\alpha-\mathrm{NH}$ group concentration in homogenized and defatted RTV was determined after total hydrolysis in $6 \mathrm{~N} \mathrm{HCl}$ at $110{ }^{\circ} \mathrm{C}$ for $24 \mathrm{~h}$, using the o-phtaldialdehyde method (OPA) reported by Nielsen et al. (2001). The number of total peptide bonds in the native protein per unit weight $(h)$ was calculated as $(\alpha \mathrm{NH}-\mathrm{B}) / A$. The values reported by Adler-Nissen (1979) are used here for $\mathrm{A}$ and $\mathrm{B}$ (1 and 0.4, respectively).

\section{Enzymatic hydrolysis}

Hydrolysis was carried out in a $500 \mathrm{~mL}$ reactor with a substrate enzyme ratio of $0.153 \mathrm{U} / \mathrm{g}$ protein and different initial concentrations of substrate $\left(\mathrm{S}_{\mathrm{o}}\right)$ (which are the peptide bonds available for hydrolysis and are given by initial concentrations of protein $\left.\mathrm{g} / \mathrm{L} \mathrm{x} h_{t}\right)$. The reactor was set at a temperature of $53{ }^{\circ} \mathrm{C}$, a pH of 9.5 and a constant agitation of $960 \mathrm{rpm}$, which were controlled by means of a combined glass electrode connected to an automatic titrator (Titrando 842, Metrohm). The reaction was monitored through $\mathrm{DH}$, expressed as the ratio between the number of hydrolyzed peptide bonds $(h)$ and $h_{t}$ (Alder-Nissen, 1979). The DH was calculated with equation 1 , using the $\mathrm{pH}$-stat method. All the hydrolysis curves were conducted with two replicates and average values were used for the models.

$\mathrm{DH}(\%)=\frac{\mathrm{B} \mathrm{N}_{\mathrm{B}}}{\mathrm{M}_{\mathrm{p}} \alpha \mathrm{h}_{\mathrm{t}}} \times 100$

where $B$ is the consumed volume of base in $m L, M_{p}$ is the mass of the protein in $\mathrm{g}, \mathrm{N}_{\mathrm{B}}$ is the concentration of the base in $\mathrm{mM}$ and $\alpha$ is the degree of dissociation of the amino groups released during the reaction. $\alpha$ and $\mathrm{pK}$ were calculated with equations 2 and 3 , respectively (Forghani et al., 2012).

$$
\begin{aligned}
& \propto=\frac{10^{\mathrm{pH}-\mathrm{pK}}}{\left(1+10^{\mathrm{pH}-\mathrm{pK}}\right)} \\
& \mathrm{pK}=7.8+\frac{(298-\mathrm{T})}{298 \cdot \mathrm{T}} \cdot 2400
\end{aligned}
$$

\section{Determination of the lipid-inhibition type on subtilisin Carlsberg}

Lineweaver-Burk graphs were used to identify the existence of any type of inhibition caused by RTV 
lipids on subtilisin Carlsberg. Hydrolysis was carried out using initial concentrations of inhibitor (extracted lipids) (I) of 1,19 and $50 \mathrm{~g} / \mathrm{L}$ and $\mathrm{S}_{\mathrm{o}}$ ranging from 34.4 to $163.4 \mathrm{mM}$. For each $\mathrm{S}_{\mathrm{o}}$, the initial reaction rate (v) was determined as the slope of the linear plot of the product concentration $(\mathrm{P})$ as a function of time; where $\mathrm{P}$ is the number of broken peptide bonds in $\mathrm{mM}$ according to equation 4 and $V_{t}$ is the total volume of the reaction in $\mathrm{L}$.

$\mathrm{P}=\frac{\mathrm{B} \mathrm{N}}{\mathrm{V}_{\mathrm{t}} \alpha}$

Although the kinetic parameters can be calculated using graphical methods, the best method for determining the inhibitor modality and the values of the inhibitor constants is to directly and globally fit all the reaction rate plots against $\mathrm{S}_{\mathrm{o}}$ and the untransformed equations for competitive, uncompetitive and mixed inhibition, equations 5, 6 and 7, respectively (Copeland, 2000). Thus, the kinetic parameters and the type of inhibition exerted by the lipids present in the viscera on subtilisin Carlsberg in the hydrolysis of RTV were determined using a global fit of equations 5 , 6 and 7; where the values of $v$ are calculated with an $I_{\circ}$ of $50 \mathrm{~g} / \mathrm{L}$ and different $\mathrm{S}$ (from 34.4 to $163.4 \mathrm{mM}$ ), using the "Isqcurvefit" function of the MATLAB $98^{\circledR}$ toolbox, which employs the trust region reflective and damped least-squares methods.

$$
\begin{aligned}
& \mathrm{v}=\frac{\left(\mathrm{V}_{\mathrm{m}} \mathrm{S}_{\mathrm{o}}\right)}{\mathrm{S}_{\mathrm{o}}+\mathrm{k}_{\mathrm{m}}\left(1+\frac{\mathrm{I}_{\mathrm{o}}}{\mathrm{k}_{\mathrm{I}}}\right)} \\
& \mathrm{v}=\frac{\left(\mathrm{V}_{\mathrm{m}} \mathrm{S}_{\mathrm{o}}\right)}{\mathrm{S}_{\mathrm{o}}\left(1+\frac{\mathrm{I}_{\mathrm{o}}}{\alpha_{\mathrm{f}} \mathrm{k}_{\mathrm{I}}}\right)+\mathrm{k}_{\mathrm{m}}\left(1+\frac{\mathrm{I}_{\mathrm{o}}}{\mathrm{k}_{\mathrm{I}}}\right)} \\
& \mathrm{v}=\frac{\left(\mathrm{V}_{\mathrm{m}} \mathrm{S}_{\mathrm{o}}\right)}{\mathrm{S}_{\mathrm{o}}\left(1+\frac{\mathrm{I}_{\mathrm{o}}}{\alpha_{\mathrm{f}} \mathrm{k}_{\mathrm{I}}}\right)+\mathrm{k}_{\mathrm{m}}}
\end{aligned}
$$

\section{Development of the model for RTV hydrolysis with subtilisin Carlsberg inhibited by lipids}

To study the enzymatic kinetics of RTV hydrolysis in the presence of lipids, we proposed a kinetic mechanism, from which we derived a semi-physical model. The same experimental hydrolysis time courses used to obtain the inhibition type were used for the simulation, modeling and parametric adjustment of the model. The input values of $\mathrm{I}_{\mathrm{o}}(1,19$ and $50 \mathrm{~g} / \mathrm{L})$, $\mathrm{S}_{\mathrm{o}}(86 \mathrm{mM})$ and $\mathrm{E}_{\mathrm{o}}(0.153 \mathrm{U} / \mathrm{g}$ protein $)$ were fixed to estimate the kinetic constants $\mathrm{K}_{\mathrm{I}}, \mathrm{k}_{2}, \mathrm{~K}_{\mathrm{m}}$, and $\mathrm{k}_{4}$, using non-linear regression analysis (Marquardt, 1963). The program was developed with the ode 45 function to solve the system of differential equations using the Runge-Kutta method (Mathews and Fink, 2000). Matlab software was used to obtain a numerical solution to the differential equation that represented the proposed model (eq. 19). The criteria used to optimize the kinetic parameters was a minimization of the residual sum of squares. To validate the model, two experimental RTV hydrolysis curves, different from those used to estimate the kinetic constants, with an $I_{0}$ of 1 and $50 \mathrm{~g} / \mathrm{L}$ and an $\mathrm{S}_{\mathrm{o}}$ of $86 \mathrm{mM}$, were used.

\section{Molecular docking of subtilisin Carlsberg and palmitic acid}

Palmitic acid was used to evaluate the molecular binding of the subtilisin Carlsberg-Inhibitor complex because it is the main fatty acid in RTV (Swapna et al., 2010). The program Avogadro 1.1.0 (Hanwell et al., 2012) was used to build the palmitic acid molecule as a ligand. The same software was employed to improve its overall structure using an energy minimization process based on the MMF94 force field by means of a steepest-descent algorithm in 500 steps. Molecular docking was carried out on a personal computer using Autodock Vina (Trott and Olson, 2010). The Subtilisin structure (PDB code 1SBC) was used for molecular modeling simulations. Protein was used without water molecules. The structure of the protein was prepared using the Protein Preparation module implemented in the Maestro program. Hydrogen atoms were automatically added to each protein according to the chemical nature of each amino acid, based on the ionized form expected in their physiological condition. This module also controls the assignment of atomic charges. Each 3D structure of the protein was relaxed through constrained local minimization, using the OPLS force fields in order to remove possible structural mismatches due to the automatic procedure employed to add the hydrogen atoms. The oxygen atom from the side chain of Ser221 (catalytic residue) was used as the center of the grid $(\mathrm{X}=81.557 \mathrm{Y}=67.687$ and $\mathrm{Z}$ $=57.984$ ), whose size was $24 \AA 3$, at exhaustiveness $=20$. Then, the ligand poses with best affinity were chosen, and a visual inspection of the interactions at the active site was performed and recorded. Molegro Molecular Viewer (MMV 2.5.0, http:// www.clcbio. com/products/molegro/\#molecular-viewer) and UCSF Chimera (www.cgl.ucsf.edu/chimera/) were used to generate the docking images.

\section{RESULTS AND DISCUSSION}

\section{Proximal chemical analysis of the viscera}

Table 1 shows the proximal chemical composition of the viscera. The results show a high lipid 
Table 1. Proximate composition of RTV.

\begin{tabular}{ccc}
\hline Composition g/100g & Viscera & Defatted viscera \\
\hline Moisture & $62.00 \pm 0.97$ & $83.21 \pm 0.05$ \\
Lipids $^{\mathrm{a}}$ & $26.08 \pm 0.81$ & $1.88 \pm 0.04$ \\
Protein $^{\mathrm{a}}$ & $7.87 \pm 0,25$ & $10.04 \pm 0.25$ \\
Ash $^{\mathrm{a}}$ & $1.19 \pm 0.04$ & $1.71 \pm 0.04$ \\
\hline
\end{tabular}

${ }^{a}$ Wet weight basis.

concentration in the viscera, $26.1 \%(\mathrm{w} / \mathrm{w})$, which demonstrates the importance of studying the effect that this component can have on the enzymatic hydrolysis of proteins. Other authors have indicated different results regarding the proximal composition of the whole viscera of different species. For example, Šližyte et al. (2005) reported similar lipid and moisture values for cod viscera, but they were higher in protein and ash, while Bhaskar et al. (2008), reported similar values for protein and ashes, but lower values for lipid content in catla viscera. Villamil et al. (2017) made a comparison of the viscera composition of eight species, and concluded that the variability in the composition depends on the species, seasonality, age, sex, consumption of nutrients, among other factors. However, these authors concluded that, in general, there is a particular interest in new strategies for the use of fish viscera since they have a high protein and oil content with long chain omega-3 fatty acids.

\section{Inhibition mechanism of RTV lipids on subtilisin Carlsberg}

Figure 1 shows the Lineweaver-Burk plots for different levels of inhibitors, in which the lipidinhibition on subtilisin Carlsberg can be seen. However,

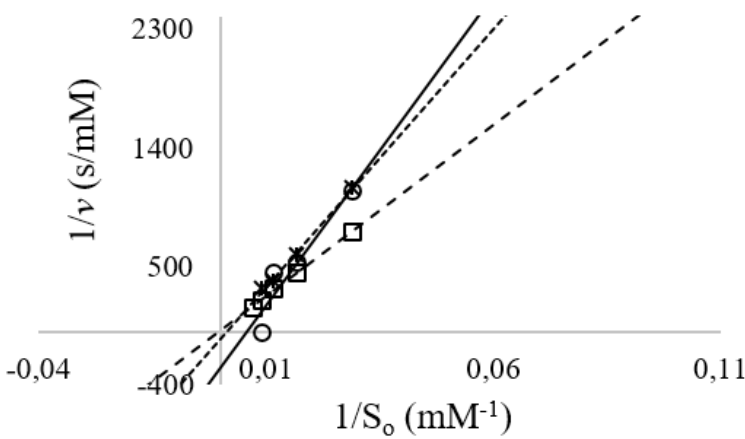

Figure 1. Lineweaver-Burk plots for RVT hydrolysis with different inhibitor concentrations: $1 \mathrm{~g} / \mathrm{L}$ (squares), $19 \mathrm{~g} / \mathrm{L}$ (circles) or $50 \mathrm{~g} / \mathrm{L}$ (asterisk). we found that a lipid concentration above $19 \mathrm{~g} / \mathrm{L}$ did not show a significant increase in the magnitude of the inhibition.

Equations 5, 6 and 7 were fitted to determine the type of inhibition. Table 2 shows the values of apparent maximum reaction rate $\left(\mathrm{V}_{\mathrm{m}}\right)$, apparent MichaelisMenten constant $\left(\mathrm{K}_{\mathrm{m}}\right)$, apparent inhibition constant $\left(\mathrm{K}_{\mathrm{r}}\right)$, factor $\alpha\left(\alpha_{f}\right)$ and statistical parameters for how well each model fits.

Considering analysis of the statistical parameters for goodness of fit, it is possible to ascertain that lipids exert competitive inhibition on subtilisin Carlsberg in the hydrolysis process of RTV. This finding can be corroborated in Figure 2. Swapna et al. (2010) analyzed for lipid class distribution and fatty acid profile of lipid extracts from tilapia (Oreochromis mossambicus) viscera. They demonstrated that neutral lipids constituted a major portion $(84.3 \pm 1.15)$ of the total lipids, while glycolipid and phospholipid contents were $10.8 \pm 0.67$ and $4.7 \pm 1.52$, respectively. Sterol esters and triacylglycerol were the major components of neutral lipids, and palmitic acid was the dominant fatty acid in the lipid extract (30.4\%).

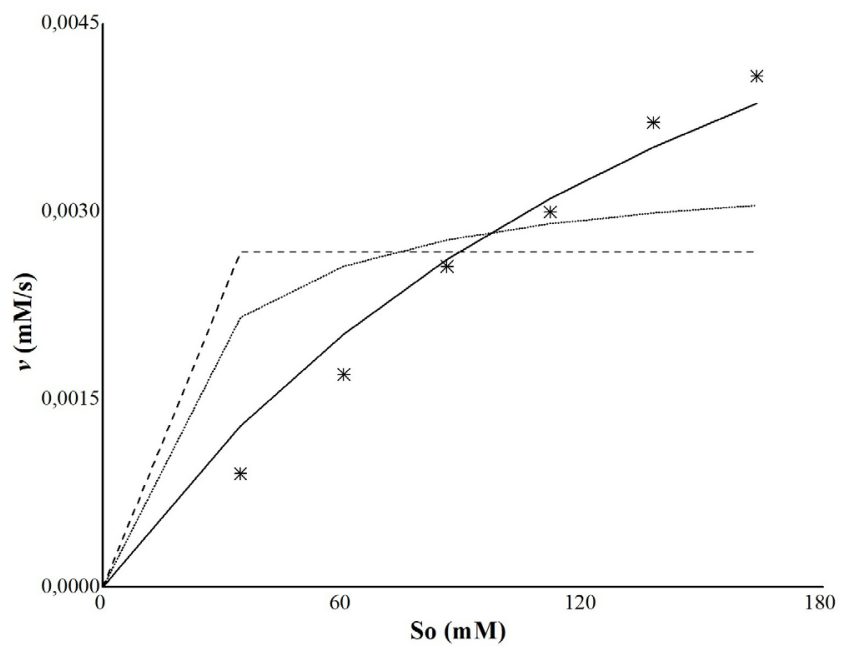

Figure2.Untransformed plots for the effects of different inhibition mechanisms on the initial hydrolysis rate of VTR with subtilisin Carlsberg. Asterisks are from experimental data and lines are from non-linear fitting using the competitive inhibition equation (continuous lines), the uncompetitive inhibition equation (dashed lines) and the mixed inhibition equation (dotted lines).

Table 2. Kinetic constants and fitting models to each inhibition type.

\begin{tabular}{cccc}
\hline Kinetic constants & Competitive & Uncompetitive & mixed \\
\hline $\mathrm{K}_{\mathrm{m}}(\mathrm{mM})$ & 54.980 & 60.010 & 0.3816 \\
$\mathrm{~V}_{\mathrm{m}}(\mathrm{mM} / \mathrm{s})$ & 0.036 & 0.670 & 0.7502 \\
$\mathrm{~K}_{\mathrm{I}}(\mathrm{g} / \mathrm{L})$ & 2.359 & 0.430 & 0.4121 \\
$\alpha_{\mathrm{f}}$ & ---- & 0.500 & 0.3341 \\
$\mathrm{R}^{2}$ & 0.9936 & 0.8029 & 0.5626 \\
Adjusted R & 0.9871 & 0.2118 & -0.7497 \\
$\mathrm{SSE}$ & $3.8 \mathrm{e}-08$ & $1.1 \mathrm{e}-06$ & $2.6 \mathrm{e}-06$ \\
$\mathrm{RMSE}$ & 0.0001 & 0.0011 & 0.0016 \\
\hline
\end{tabular}


The $h$ found for RTV proteins was $8.22 \mathrm{mmol} /$ $\mathrm{g}_{\text {prot }}$, which is close to the value reported for this type of proteins and is within the range of published values (7.5-11.1 mmol $/ \mathrm{g}_{\text {prot }}$ ) (Nielsen et al., 2001; Valencia et al., 2014). As shown in Table 2, a value of $6.69 \mathrm{~g} / \mathrm{L}$ was found for $\mathrm{K}_{\mathrm{m}}$ (calculated by dividing the $\mathrm{K}_{\mathrm{m}}$ in $\mathrm{mM}$ by $h$ ). This value is close to that obtained by Valencia et al. (2014), which was $9.54 \mathrm{mM} \approx 4 \mathrm{~g} / \mathrm{L}$ for hydrolysis with subtilisin Carlsberg in salmon fillet; but smaller than the one found by Charoenphun et al. (2013), who determined the kinetic parameters of hydrolysis with subtilisin Carlsberg in Nile tilapia muscle proteins and found a $\mathrm{K}_{\mathrm{m}}$ value of $33.7 \mathrm{~g} / \mathrm{L}$. Thus, considering that $\mathrm{K}_{\mathrm{m}}$ is a relative measure of the affinity of the formation of the ES complex, the results suggest that subtilisin Carlsberg has a greater affinity for the protein in tilapia viscera, than for protein in muscle. Regarding the competitive inhibition constant, the value $(2.36 \mathrm{~g} / \mathrm{L})$ was less than $\mathrm{K}_{\mathrm{m}}$, which means that the formation of the enzymeinhibitor complex (EI) is favored at the expense of the ES complex. This clearly indicates a strong inhibition by the RTV lipids in the initial phase of the hydrolysis reaction.

\section{Phenomenological modeling and parameter estimation}

The enzymatic reaction mechanism in the presence of a competitive inhibitor is illustrated in the scheme shown in Figure 3, in which the free enzyme (E) and the free substrate (S) are reversibly bound to form the enzyme- substrate complex (ES) and obtain the product $\mathrm{P}$, where $k_{m}=\left(k_{-1}+k_{2}\right) / k_{1}$ represents the MichaelisMenten constant. EI is a $k_{I}=k_{-3} / k_{3}$ dead-end complex, as the only reaction that it can undergo is reformation of $\mathrm{E}+\mathrm{I}$. Therefore, its concentration is given by a true equilibrium constant, $k_{I}=k_{-3} / k_{3}$, also called competitive inhibition (Cornish-Bowden, 2012).

In this regard, the reaction depends on the irreversible step. Based on the material balances, the rate of the reaction can be shown as:

$$
\mathrm{v}=\mathrm{S}_{\mathrm{o}} \frac{\mathrm{d}(\mathrm{DH})}{\mathrm{dt}}=\mathrm{k}_{2}[\mathrm{ES}]
$$

During the process of enzymatic protein hydrolysis, proteases can undergo an inactivation process, which can be simplified as

$$
\begin{gathered}
\stackrel{k_{3}}{\rightleftarrows} \mathrm{E} \\
k_{-3} \\
\mathrm{E}+\mathrm{S} \underset{k_{-1}}{\stackrel{k_{1}}{\rightleftarrows}} \mathrm{ES} \stackrel{k_{2}}{\rightarrow} \mathrm{E}+\mathrm{P}
\end{gathered}
$$

Figure 3. Equilibrium scheme for enzyme turnover in the presence of a competitive inhibitor.

$$
\mathrm{E}+\mathrm{ES} \stackrel{\mathrm{k} 4}{\rightarrow} \mathrm{E}_{\mathrm{a}}+\mathrm{E}_{\mathrm{i}}+\mathrm{P}
$$

where is the active form of the enzyme and is the inactive form of the enzyme, as reported by Qi and $\mathrm{He}$ (2006). Therefore, the reaction rate of the enzyme inactivation reaction can be shown as:

$$
-\frac{\mathrm{de}}{\mathrm{dt}}=\mathrm{k}_{4}[\mathrm{ES}][\mathrm{E}]
$$

By dividing Eq. 8 by Eq. 9, Eq. 10 can be derived:

$$
-\mathrm{S}_{\mathrm{o}} \frac{\mathrm{dDH}}{\mathrm{de}}=\frac{\mathrm{k}_{2}}{\mathrm{k}_{4}[\mathrm{E}]}
$$

Based on mass balances and in terms of a steadystate approach for the balanced reaction, the following equations can be deduced:

$[\mathrm{EI}]=\frac{[\mathrm{E}][\mathrm{I}]}{\mathrm{k}_{\mathrm{I}}}$

$[\mathrm{ES}]=\frac{[\mathrm{E}][\mathrm{S}]}{\mathrm{k}_{\mathrm{m}}}$

$[\mathrm{E}]=\frac{\mathrm{k}_{-1}[\mathrm{ES}]+\mathrm{k}_{2}[\mathrm{ES}]+\mathrm{k}_{-3}[\mathrm{EI}]}{\mathrm{k}_{1}[\mathrm{~S}]+\mathrm{k}_{3}[\mathrm{I}]}$

Total enzyme concentration can be expressed as:

$$
\mathrm{e}=[\mathrm{E}]+[\mathrm{ES}]+[\mathrm{EI}]
$$

Through the substitution of Eqs. 11-13 into Eq. 14, Since $[\mathrm{S}] \approx \mathrm{S}_{\mathrm{o},}[\mathrm{I}] \approx \mathrm{I}_{\mathrm{o}}$, Eq. 15 is obtained:

$$
[E]=\frac{e k_{m} k_{I}}{k_{m} k_{I}+k_{I} S_{o}+k_{m} I_{o}}
$$

By combining Eqs. 15 and 12, Eq. 16 can be derived:

$$
[E S]=\frac{\mathrm{k}_{\mathrm{I}} \mathrm{S}_{\mathrm{o}}}{\mathrm{k}_{\mathrm{m}} \mathrm{k}_{\mathrm{I}}+\mathrm{k}_{\mathrm{I}} \mathrm{S}_{\mathrm{o}}+\mathrm{k}_{\mathrm{m}} \mathrm{I}_{\mathrm{o}}} \times \mathrm{e}
$$

By combining Eqs. 15 and 10, the following equation is obtained:

$$
-\frac{\mathrm{dDH}}{\mathrm{de}}=\frac{\mathrm{k}_{2}\left(\mathrm{k}_{\mathrm{m}} \mathrm{k}_{\mathrm{I}}+\mathrm{k}_{\mathrm{I}} \mathrm{S}_{\mathrm{o}}+\mathrm{k}_{\mathrm{m}} \mathrm{I}_{\mathrm{o}}\right)}{\mathrm{k}_{4} \mathrm{k}_{\mathrm{m}} \mathrm{k}_{\mathrm{I}} \mathrm{S}_{\mathrm{o}}} \times \frac{1}{\mathrm{e}}
$$

Integration of Eq. 17 give us: 


$$
\mathrm{e}=\mathrm{E}_{\mathrm{o}} \times \exp \left[-\mathrm{DH} \times \frac{\mathrm{k}_{4} \mathrm{k}_{\mathrm{m}} \mathrm{k}_{\mathrm{I}} \mathrm{S}_{\mathrm{o}}}{\mathrm{k}_{2}\left(\mathrm{k}_{\mathrm{m}} \mathrm{k}_{\mathrm{I}}+\mathrm{k}_{\mathrm{I}} \mathrm{S}_{\mathrm{o}}+\mathrm{k}_{\mathrm{m}} \mathrm{I}_{\mathrm{o}}\right)}\right]
$$

The model equation, Eq. 19, obtained by combining Eqs. 16 and 18, was used to fit the experimental data.

$$
\begin{aligned}
\frac{\mathrm{dDH}}{\mathrm{dt}} & =\frac{\mathrm{k}_{2} \mathrm{k}_{\mathrm{I}} \mathrm{E}_{\mathrm{o}}}{\mathrm{k}_{\mathrm{m}} \mathrm{k}_{\mathrm{I}}+\mathrm{k}_{\mathrm{I}} \mathrm{S}_{\mathrm{o}}+\mathrm{k}_{\mathrm{m}} \mathrm{I}_{\mathrm{o}}} \times \\
& \times \exp \left[-\mathrm{DH} \times \frac{\mathrm{k}_{4} \mathrm{k}_{\mathrm{m}} \mathrm{k}_{\mathrm{I}} \mathrm{S}_{\mathrm{o}}}{\mathrm{k}_{2}\left(\mathrm{k}_{\mathrm{m}} \mathrm{k}_{\mathrm{I}}+\mathrm{k}_{\mathrm{I}} \mathrm{S}_{\mathrm{o}}+\mathrm{k}_{\mathrm{m}} \mathrm{I}_{\mathrm{o}}\right)}\right]
\end{aligned}
$$

According to the hydrolysis curves obtained with $\mathrm{S}_{\mathrm{o}}$ of $86 \mathrm{mM}$ and $\mathrm{I}_{\mathrm{o}}$ of 1,19 and $50 \mathrm{~g} / \mathrm{L}$ (Fig. 4A), the values of the kinetic constants $\mathrm{K}_{\mathrm{I}}, \mathrm{k}_{2}, \mathrm{~K}_{\mathrm{m}}$, and $\mathrm{k}_{4}$ obtained from the non-linear regression analysis of equation 19 , were: $3.013 \mathrm{~g} / \mathrm{L}, 0.15 \mathrm{mM} / \mathrm{s}, 60.46 \mathrm{mM}$ and $0.00004^{\mathrm{s}-1}$ respectively, with an $\mathrm{R}^{2}$ of 0.917 and an adjusted $\mathrm{R}^{2}$ of 0.904 .

The value obtained for $\mathrm{K}_{\mathrm{m}}$ with the new proposed model (at $60.46 \mathrm{mM} \approx 7.35 \mathrm{~g} / \mathrm{L}$ ), is within the range of magnitudes reported by other authors for hydrolysis with subtilisin Carlsberg of different protein substrates (Charoenphun et al., 2013; Tardioli et al., 2005; Valencia et al., 2014). Additionally, this coincides with the value obtained in this study from the MichaelisMenten equation for competitive inhibition (Table 2). Similarly, the competitive inhibition constants established for equations 5 and 19, 2.359 and 3.013 $\mathrm{g} / \mathrm{L}$ respectively, are very close. In both cases, the
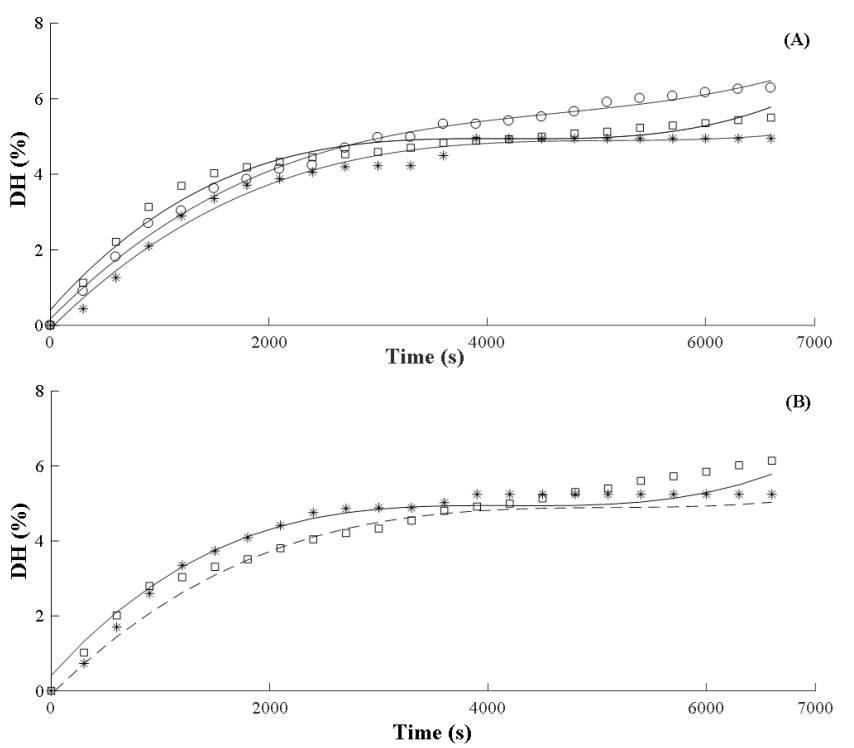

Figure 4. Experimental hydrolysis time courses with $I_{0}$ of $1 \mathrm{~g} / \mathrm{L}$ (squares), $19 \mathrm{~g} / \mathrm{L}$ (circles) or $50 \mathrm{~g} / \mathrm{L}$ (asterisk); and predictions obtained using the novel model (Eq. 19) with $\mathrm{I}_{\mathrm{o}}$ of $1 \mathrm{~g} / \mathrm{L}$ (continuous lines), $19 \mathrm{~g} / \mathrm{L}$ (Dashdot line) or $50 \mathrm{~g} / \mathrm{L}$ (dashed lines). (A): Parametric fit of the data for the model. (B): Validation of the model with new experimental data. constants point to a strong inhibition mechanism by the RTV lipids on the hydrolysis reaction, given that $\mathrm{K}_{\mathrm{I}}$ is less than $\mathrm{K}_{\mathrm{m}}$. However, it is important to consider that both are based on measurements of the consumed base as a function of time.

The model was validated with additional experimental data, obtained under the same conditions and the results are presented in Figure 4B. The high correlation coefficients of the simulated curves in relation to the experimental ones $\left(0.97\right.$ and 0.99 for $\mathrm{I}_{\mathrm{o}}$ of 1 and $50 \mathrm{~g} / \mathrm{L}$, respectively), suggests that the model effectively explains the hydrolysis reaction of RTV with subtilisin Carlsberg with lipid inhibition. The correlation also suggests that it is possible to use this model to predict the hydrolysis kinetics, depending on the initial concentration of the substrate and inhibitor under the reaction conditions of the study.

The fact that serine proteinases such as subtilisin Carlsberg follow Michaelis-Menten kinetics when acting on peptide bonds (Whitaker, 1994) and that the models that were evaluated are a good fit, proves that subtilisin Carlsberg undergoes competitive inhibition by the lipids present in RTV during the enzymatic hydrolysis of its proteins.

\section{Molecular Docking}

Molecular docking results suggested that palmitic acid binds to the enzyme with a theoretical affinity of $-6.8 \mathrm{kcal} / \mathrm{mol}$. Our results also suggested that the fatty acid forms van der Waals interactions with residues of the His64, Asn 155 and Ser225 active sites, as well as others involved in the binding of the substrate (Figs. 5 and 6$)$.

Additionally, molecular docking suggested that palmitic acid also forms hydrogen bonds with two active site amino acids (His64, Asn155) and occupies part of the substrate binding cleft (Fig. 7). The N $\varepsilon 2$ of His64 is responsible for extracting the proton from the hydroxyl group of the side chain of Ser225, which

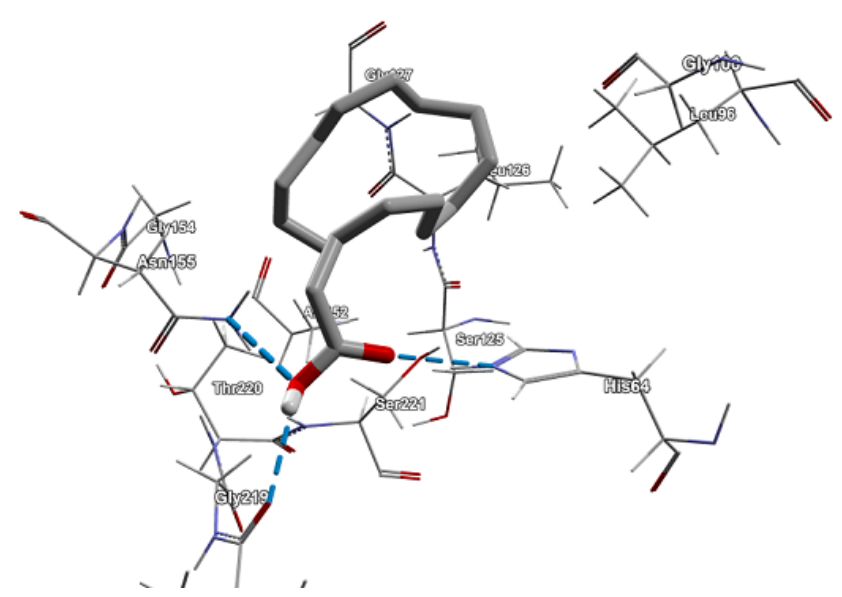

Figure 5. Interaction of palmitic acid with the active site of Subtilisin. Dotted blue lines represent H-bonds. All residues at a distance lower than $3.5 \AA$ are shown. 


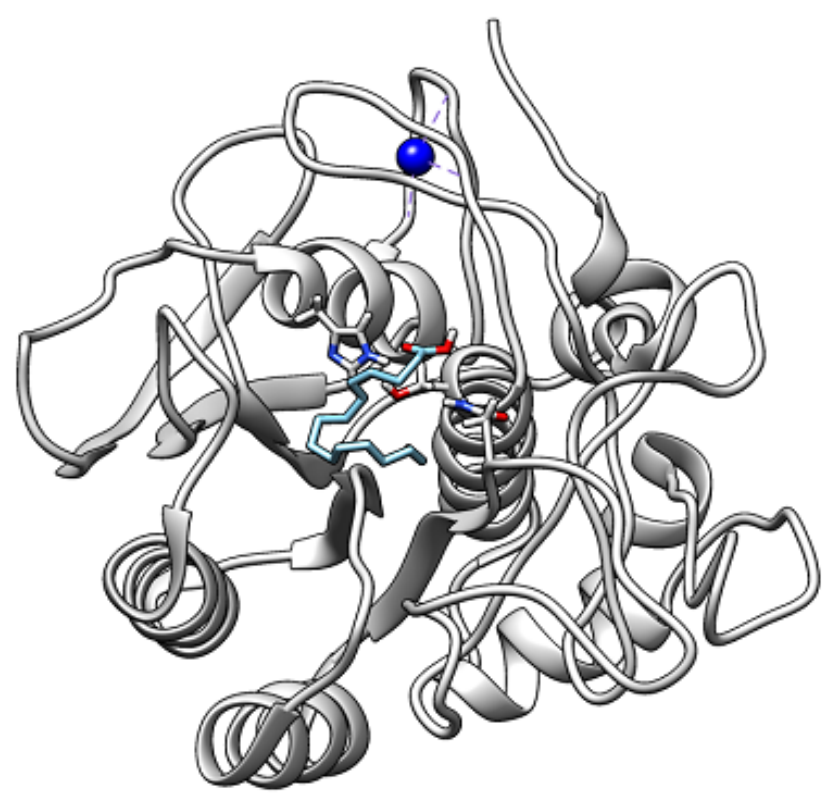

Figure 6. Interaction of palmitic acid with the active site of Subtilisin. The catalytic triad of the enzymes is shown in sticks with Carbon atoms in gray, oxygen in red, nitrogen in blue and hydrogen in white (His64, Asn 155 and Ser225). Carbons of palmitic acid are displayed in magenta, oxygens in red and hydrogen in white. The blue sphere is a $\mathrm{Ca}^{2+}$ ion and the blue dashed lines represent coordinated bonds between the ion and enzyme.

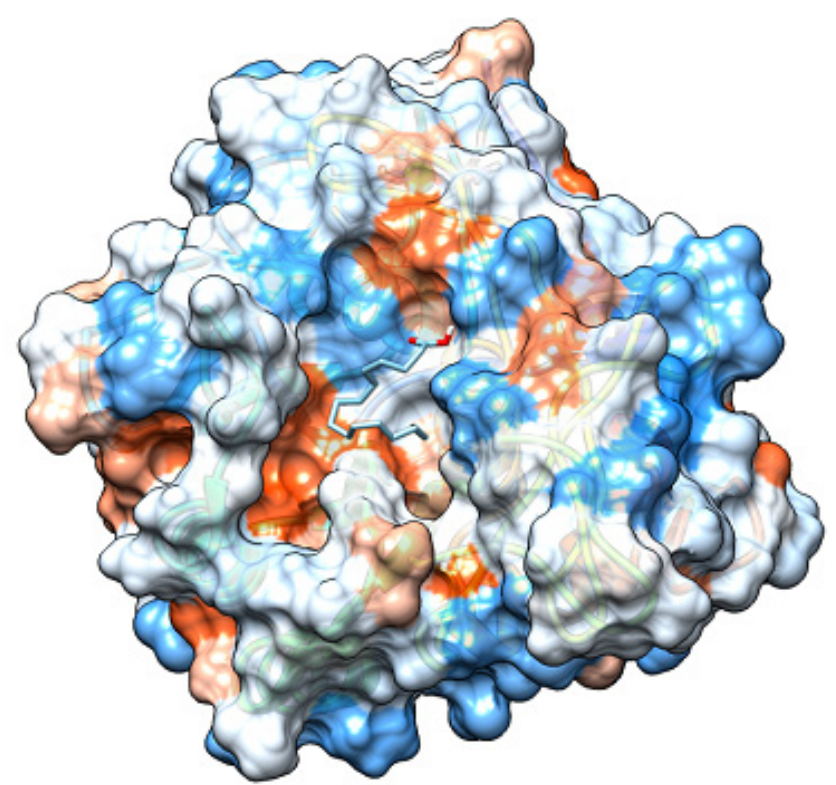

Figure 7. Molecular surface of Subtilisin and interaction of palmitic acid with the substrate binding cleft and the active site of the protein. The red areas of the surface represent the acid regions; the white areas represent the neutral and the blue areas the basic regions. Palmitic acid is shown as magenta (carbon) white (hydrogen atoms) and red sticks (oxygen atoms). forms an oxyanion that exerts a nucleophilic attack on the carbonyl of the peptide bond that is going to be hydrolyzed (Hedstrom, 2002). Therefore, the hydrogen bond with His64 could affect the possibility that amino acid can generate the nucleophile that initiates the catalytic mechanism of serine proteinase. Furthermore, the Gly100 and Ser125 residues are part of the substrate binding subsites S1 and S4' (Hedstrom, 2002; Perona and Craik, 1995). Thus, the van der Waals interactions with these amino acids would cause a partial occupation of the substrate binding cleft and a subsequent steric hindrance to bind it. Similar findings were obtained with succinic acid, which interacted with the His57 (catalytic residue) of Trypsin (Manohar et al., 2018).

The molecular docking analysis suggests that palmitic acid competes with tilapia viscera proteins for the active site of subtilisin Carlsberg. This finding could be generalized to fatty acids, because the molecular structure of a fatty acid is basically the same in terms of its carboxylic group and hydrocarbon chain. The previous analysis reinforces the hypothesis of competitive inhibition shown by the two models that were studied.

\section{CONCLUSIONS}

RTV contain high lipid levels, which act as an inhibitor of subtilisin Carlsberg in the enzymatic hydrolysis reaction of proteins. Inhibition occurs through a competitive mechanism of inhibition, possibly due to the molecular coupling that occurs between fatty acids and the active site of subtilisin.

\section{ACKNOWLEDGMENTS}

The authors are grateful for the financial support provided by the Comité para el Desarrollo de la Investigación of the Universidad de Antioquia (CODI) through its 2016-2017 sustainability program.

\section{REFERENCES}

Alder-Nissen, J. Determination of the DH of food protein hydrolysates by trinitrobenzenesulfonic acid, Journal of Agricultural and Food Chemistry, 27, 1256-1262 (1979). https://doi.org/10.1021/ jf60226a042

AOAC. Official Methods of Analysis (17th ed.). Association of Official Analytical Chemists, Washington, D.C (2006).

Batista, I., Ramos, C., Coutinho, J., Bandarra, N. M., Nunes, M. L. Characterization of protein hydrolysates and lipids obtained from black scabbardfish (Aphanopus carbo) by-products and antioxidative activity of the hydrolysates produced, Process Biochemistry, 45, 18-24 (2010). http://doi. org/10.1016/j.procbio.2009.07.019 
Bhaskar, N., Mahendrakar, N. S. Protein hydrolysate from visceral waste proteins of Catla (Catla catla): Optimization of hydrolysis conditions for a commercial neutral protease, Bioresource Technology, 99, 4105-4111 (2008). http://doi. org/10.1016/j.biortech.2007.09.006

Charoenphun, N., Youravong, W., Cheirsilp, B. Determination of reaction kinetics of hydrolysis of tilapia (Oreochromis niloticus) protein for manipulating production of bioactive peptides with antioxidant activity, angiotensin-I-converting enzyme inhibitory activity and Ca-binding properties, International Journal of Food Science and Technology, 48, 419-428 (2013). http://doi. org/10.1111/j.1365-2621.2012.03204.x

Copeland, R. A. Enzymes: A Practical Introduction to Structure, Mechanism, and Data Analysis ( $2^{\text {nd }}$ ed.). I. Wiley-VCH, New York (2000).

Cornish-Bowden, A. Fundamentals of Enzyme Kinetics ( $4^{\text {th }}$ ed.). Wiley- Blackwell, Weinheim (2012).

Demirhan, E., Apar, D. K., Özbek, B. A Kinetic Study on Sesame Cake Protein Hydrolysis by Alcalase, Journal of Food Science, 76, C64-C67 (2011). http://doi.org/10.1111/j.1750-3841.2010.01938.x

Figueroa, O., Zapata, J., Gutiérrez, G. Modelamiento de la cinética de hidrólisis enzimática de proteínas del plasma bovino, Escuela de Ingeniería de Antioquia, 17, 71-84 (2012).

Fischer, M., Kofod, L., Schols, H., Piersma, S., Gruppen, H., Voragen, A. Enzymatic Extractability of Soybean Meal Proteins and Carbohydrates: Heat and Humidity Effects Title, Journal of Agricultural and Food Chemistry, 49, 4463-4469 (2001). http:// doi.org/10.1021/jf010061w

Forghani, B., Ebrahimpour, A., Bakar, J., Hamid, A. A., Hassan, Z., Saari, N. Enzyme Hydrolysates from Stichopus horrens as a New Source for Angiotensin-Converting Enzyme Inhibitory Peptides, Evidence-Based Complementary and Alternative Medicine, 2012, 1-9 (2012). http:// dx.doi.org/10.1155/2012/236384

Gómez, L. J., Zapata, J. E. Efecto del Nivel de Grasa y Velocidad de Agitación en la Hidrolisis Enzimática de Vísceras de Tilapia Roja (Orechromis sp.), Información Tecnológica, 28, 47-56 (2017). http:// doi.org/10.4067/S0718-07642017000400007

Hanwell, M. D., Curtis, D. E., Lonie, D. C., Vandermeersch, T., Zurek, E., Hutchison, G. R. Avogadro: an advanced semantic chemical editor, visualization, and analysis platform, Journal of Cheminformatics, 4, 1-17 (2012). http://doi. org/10.1186/1758-2946-4-17

Hathwar, S. C., Bijinu, B., Rai, A. K., Narayan, B. Simultaneous Recovery of Lipids and Proteins by enzymatic hydrolysis of fish industry waste using different commercial proteases, Applied Biochemistry and Biotechnology, 164, 115-124 (2011). http://doi.org/10.1007/s12010-010-9119-5

He, S., Franco, C., Zhang, W. Functions, applications and production of protein hydrolysates from fish processing co-products (FPCP), Food Research International, 50, 289-297 (2013). http://doi. org/10.1016/j.foodres.2012.10.031

Hedstrom, L. Serine Protease Mechanism and Specificity, Chemical Reviews, 102, 4501-4524 (2002). http://doi.org/10.1021/cr000033x

Manohar, R., Kutumbarao, N. H. V., Krishna Nagampalli, R. S., Velmurugan, D., Gunasekaran, K. Structural insights and binding of a natural ligand, succinic acid with serine and cysteine proteases, Biochemical and Biophysical Research Communications, 495, 679-685 (2018). https://doi. org/10.1016/j.bbrc.2017.11.033

Marquardt, D. W. An Algorithm for Least-Squares Estimation of Nonlinear Parameters, Journal of the Society for Industrial and Applied Mathematics, 11, 431-441 (1963).

Marquez, M. C., Fernandez, V. Enzymic hydrolysis of vegetable proteins: mechanism and kinetics, Process Biochemistry, 28, 481-490 (1993). http:// dx.doi.org/10.1016/0032-9592(93)85032-B

Martínez, N., Martínez, A., Dávila, G. Determination of antioxidant and chelating activity of protein hydrolysates from spirulina (Arthrospira maxima) obtained by simulated gastrointestinal digestion, Revista Mexicana de Ingeniería Química, 14, 2534 (2015).

Mathews, J., Fink, K. Métodos Numéricos con MATLAB ( $3^{\text {rd }}$ ed.). P. Hall, Madrid (2000).

Morales, R., Pérez, R., Guadix, A., Guadix, E. M. Artificial neuronal network modeling of the enzymatic hydrolysis of horse mackerel protein using protease mixtures, Biochemical Engineering Journal, 105, 364-370 (2016). http://doi. org/10.1016/j.bej.2015.10.009

Nielsen, P. M., Petersen, D., Dambmann, C. Improved Method for Determining Food Protein Degree of Hydrolysis, Journal of Food Science, 66, 642-646 (2001). http://doi.org/10.1111/j.1365-2621.2001. tb04614.x

Ojha, K. S., Alvarez, C., Kumar, P., O’Donnell, C. P., Tiwari, B. K. Effect of enzymatic hydrolysis on the production of free amino acids from boarfish (Capros aper) using second order polynomial regression models, LWT - Food Science and Technology, 68, 470-476 (2016). http://doi. org/10.1016/j.lwt.2015.11.040

Pérez, R., Almécija, M. C., Espejo, F. J., Guadix, E. M., Guadix, A. Bi-objective optimisation of the enzymatic hydrolysis of porcine blood protein, Biochemical Engineering Journal, 53, 305-310 (2011). http://doi.org/10.1016/j.bej.2010.12.004 
Perona, J. J., Craik, C. S. Structural basis of substrate specificity in the serine proteases, Protein Science: A Publication of the Protein Society, 4, 337-360 (1995).

Qi, W., He, Z. Enzymatic hydrolysis of protein: Mechanism and kinetic model, Frontiers of Chemistry in China, 1, 308-314 (2006). http://doi. org/10.1007/s11458-006-0026-9

Rawel, H. M., Czajka, D., Rohn, S., Kroll, J. Interactions of different phenolic acids and flavonoids with soy proteins, International Journal of Biological Macromolecules, 30, 137-150 (2002). http://doi. org/10.1016/S0141-8130(02)00016-8

Šližyte, R., Daukšas, E., Falch, E., Storrø, I., Rustad, T. Characteristics of protein fractions generated from hydrolysed cod (Gadus morhua) by-products, Process Biochemistry, 40, 2021-2033 (2005). http://doi.org/10.1016/j.procbio.2004.07.016

Swapna, H. C., Rai, A. K., Bhaskar, N., Sachindra, N. M. Lipid classes and fatty acid profile of selected Indian fresh water fishes, Journal of Food Science and Technology, 47, 394-400 (2010). http://doi. org/10.1007/s13197-010-0065-6

Tardioli, P. W., Sousa, R., Giordano, R. C., Giordano, R. L. C. Kinetic model of the hydrolysis of polypeptides catalyzed by Alcalase ${ }^{\circledR}$ immobilized on $10 \%$ glyoxyl-agarose, Enzyme and Microbial
Technology, 36, 555-564 (2005). http://doi. org/10.1016/j.enzmictec.2004.12.002

Trott, O., Olson, A. J. AutoDock Vina: improving the speed and accuracy of docking with a new scoring function, efficient optimization and multithreading, Journal of Computational Chemistry, 31, 455-461 (2010). http://doi.org/10.1002/jcc.21334

Trusek-Holownia, A. Production of protein hydrolysates in an enzymatic membrane reactor, Biochemical Engineering Journal, 39, 221-229 (2008). http://dx.doi.org/10.1016/j.bej.2007.09.010

Valencia, P., Espinoza, K., Ceballos, A., Pinto, M., Almonacid, S. Novel modeling methodology for the characterization of enzymatic hydrolysis of proteins, Process Biochemistry, 50, 589-597 (2015). http://doi.org/10.1016/j.procbio.2014.12.028

Valencia, P., Pinto, M., Almonacid, S. Identification of the key mechanisms involved in the hydrolysis of fish protein by Alcalase, Process Biochemistry, 49, 258-264 (2014). http://doi.org/10.1016/j.procbio.2013.11.012

Villamil, O., Váquiro, H., Solanilla, J. F. Fish viscera protein hydrolysates: Production, potential applications and functional and bioactive properties, Food Chemistry, 224, 160-171 (2017). http://doi.org/10.1016/j.foodchem.2016.12.057

Whitaker, J. R. Principles of Enzymology for Food Science ( $2^{\text {nd }}$ ed.). CRC Press, New York (1994). 
